Mirjana Tukar

predsednik Veća za prekršaje u Novom Sadu

\title{
ŽALBA, BITNE POVREDE ODREDABA PREKRŠAJNOG POSTUPKA I PONAVLJANJE POSTUPKA*
}

\section{ŽALBA}

Novim Zakonom o prekršajima koji je objavljen u „Službenom glasniku Republike Srbije" broj 101 od 21. 11. 2005. godine, a koji se primenjuje od 01. 01. 2007. godine, kao jedini redovan pravni lek propisana je žalba.

Članom 228. Zakona je propisano da se protiv odluke donete u prvom stepenu može izjaviti žalba Višem prekršajnom sudu, a da se žalba predaje sudu odnosno organu uprave koji je doneo prvostepenu odluku. Iz ove odredbe proizilazi da na svaku odluku, sem one povodom koje je propisano da nije dozvoljena žalba ili nije dozvoljena posebna žalba, a to su rešenja i presude, može se izjaviti žalba Višem prekršajnom sudu. Rok za podnošenje žalbe je kao i u sada važećem Zakonu o prekršajima 8 dana od dana usmeno saopštene odluke odnosno dana dostavljanja presude ili rešenja. Dakle, žalba se po pravilu i po zakonu, predaje sudu koji je doneo prvostepenu odluku, ali ukoliko se pogrešno uputi Višem prekršajnom sudu smatraće se da je žalba blagovremena ukoliko je drugostepenom sudu upućena u roku od 8 dana od dana usmeno saopštene odluke, odnosno dostavljanja presude ili rešenja. Rok za žalbu teče od dana usmenog saopštavanja odluke. U tom slučaju rok za žalbu podnosioca zahteva koji nije bio prisutan usmenom saopštavanju odluke teče od dana dostavljanja izreke usmeno saopštene odluke. Međutim, u situaciji kada učesnici u postupku koji imaju pravo žalbe zahtevaju da im se odluka o prekršaju dostavi u overenom prepisu sa obrazloženjem, rok za žalbu teče od dana prijema overenog prepisa usmeno objavljene presude ili rešenja

* Rad primljen: 05. VI 2006. godine. 
sa obrazloženjem. Pored toga, u slučaju da je na zahtev okrivljenog overeni prepis presude ili rešenja dostavljen i njegovom braniocu, a isti ovaj akt primi kasnije od okrivljenog, rok za žalbu u tom slučaju teče od dana kada je branilac primio takav akt.

Žalbu na rešenje o prekršaju mogu izjaviti okrivljeni i podnosilac zahteva, a u korist okrivljenog, žalbu mogu izjaviti njegov branilac, bračni drug, srodnik po krvi u prvoj liniji, brat, sestra, zakonski zastupnik, usvojitelj, usvojenik, hranitelj i ono što je novina u Zakonu o prekršajima, žalbu može da izjavi i lice sa kojim okrivljeni živi u vanbračnoj zajednici. Ova novina je uvedena imajući u vidu novi porodični zakon u kome se u mnogim pravima i obavezama bračna i vanbračna zajednica izjednačavaju. U korist okrivljenog pravnog lica žalbu može izjaviti predstavnik pravnog lica, kao i fizičko lice ovlašćeno da ga predstavlja ili zastupa. Ovo bi u praksi značilo da žalbu u korist okrivljenog pravnog lica može da izjavi osnivač pravnog lica, odnosno direktor pravnog lica, a to je lice koje je aktom o osnivanju pravnog lica odgovorno za zakonitost rada tog pravnog lica. Ovakva novina u znatnoj meri otklanja određene nedoumice koje sada postoje, a to je pitanje da li direktor koji je u istom prekršajnom postupku i odgovorno lice, može da izjavi žalbu u korist pravnog lica.

Žalba ima suspenzivno dejstvo, dakle odlaže izvršenje odluke sem u slučajevima propisanim članom 294. Zakona o prekršajima, kojim se propisuje izvršenje osuđujuće presude pre njene pravosnažnosti.

Okrivljeni i podnosilac zahteva mogu se odreći prava na žalbu pošto je odluka saopštena, a od izjavljene žalbe mogu odustati do donošenja drugostepene presude. Odricanje i odustajanje od prava na žalbu se ne mogu opozvati. Maloletnik se ne može odreći od prava na žalbu, a ukoliko takvo odricanje i postoji isto ne proizvodi pravna dejstva. Odricanje od prava na žalbu mora se zabeležiti na zapisniku o usmenom pretresu i takvu izjavu okrivljeni, odnosno podnosilac zahteva moraju potpisati da bi se ista smatrala pravno valjanom. Ukoliko bi nakon odricanja od žalbe ova lica izjavila žalbu, ista bi bila odbačena kao nedozvoljena. Imajući u vidu da okrivljeni i podnosilac zahteva imaju pravo slobodnog raspolaganja žalbom, u situaciji kada se isti odreknu prava na žalbu, a lica koja u njihovu korist na osnovu člana 229. istu izjave, ovakva žalba će biti odbačena kao nedozvoljena. Iz svega navedenog proizilazi da odricanje, odnosno odustajanje od žalbe, koja je pravno valjano data, ne može se opozvati.

Po novom Zakonu o prekršajima novina je i sadržaj žalbe. U sada važećem Zakonu, žalba se smatra potpunim podneskom ukoliko sadrži oznaku rešenja i organa za prekršaje na koji se izjavljuje, i potpis žalioca. U novom Zakonu o prekršajima uveden je još jedan obavezan element žalbe, a to je navod u čemu je podnosilac žalbe nezadovoljan odlukom. Iz ove zakonske odredbe proizilazi pitanje šta treba uraditi ukoliko žalba ne sadrži sve ove obavezne elemente. Sa ovakvom žalbom, prvostepeni sud je dužan da postupi kao sa neurednim podneskom, da zatraži od žalioca 
da žalbu u određenom roku učini urednom, pa onda prosledi žalbu Višem prekršajnom sudu. Ukoliko u određenom roku žalilac ne dopuni žalbu, ista se odbacuje kao neuredan podnesak.

U žalbi se mogu iznositi nove činjenice i predlagati novi dokazi ali je u toj situaciji žalilac dužan da navede dokaze kojima bi se te činjenice imale dokazati, i dužan je navesti zašto te dokaze nije ranije izneo.

Prvostepeni sud je dužan da kada zaprimi žalbu, istu ispita u smislu člana 238. Zakona o prekršajima, odnosno da ispita da li je ista blagovremena, da li je dozvoljena i da li je izjavljena od strane ovlašćenog lica.

Blagovremenost žalbe je vezana za računanje rokova i najčešći problem na koje drugostepene sudije nailaze je pogrešno računanje rokova, naročito u situacijama kada poslednji dan roka za izjavljivanje žalbe spada u neradni dan, odnosno vikend ili praznik. Zbog toga nisu retke situacije kada prvostepeni sudija nezakonito žalbu odbaci kao neblagovremenu.

Da li je žalba dozvoljena, najviše zavisi od zakonskih odredbi jer postoje odluke u prekršajnom postupku (zaključak kojim se prekršajni postupak pokreće i sl.), protiv kojih žalba nije dozvoljena, ili situacije (rešenje o odbijanju zahteva za izuzeće) kada nije dozvoljena posebna žalba. U tim situacijama prvostepeni sudija je dužan da žalbu kao nedozvoljenu odbaci. U novom Zakonu o prekršajima će se kao češći slučaj mogućnosti odbacivanja žalbe kao nedozvoljene pojavljivati u situaciji kada se okrivljeni odrekao prava na žalbu, što je u zapisniku svojeručno potpisao a kasnije se ipak predomislio i žalbu izjavio. I u tim situacijama treba doneti ovakvu odluku.

Najčešći slučaj izjavljivanja žalbe od strane neovlašćenog lica je slučaj kada advokat, koji pri tom nema urednu punomoć, izjavi žalbu. Sada važeći stav Veća za prekršaje u Novom Sadu je da se u takvim slučajevima žalba odbacuje kao izjavljena od strane neovlašćenog lica, za razliku od prethodnog stava koji je obavezivao prvostepenog sudiju da u takvim situacijama postupa kao sa neurednim podneskom, odnosno da od advokata traži da žalbu uredi urednom punomoći. Razlog za ovakav promenjen stav našeg Veća je obaveza branioca propisana članom 109. st. 4. Zakona o prekršajima, a to je dužnost branioca da podnese punomoćje sudu, odnosno organu uprave pred kojim se vodi postupak, kao i mogućnost da okrivljeni može braniocu dati usmeno punomoćje na zapisnik kod suda odnosno organa uprave. Kako branilac okrivljenog koji je shodno članu 109. st. 1. Zakona o prekršajima isključivo advokat, odnosno u slučaju zamene advokatski pripravnik, a pri tom se ne radi o neukim strankama, ovo veće smatra da nepodnošenje punomoćja u toku postupka ili prilikom izjavljivanja žalbe, može da predstavlja svojevrsnu zloupotrebu prava od strane advokata. Dakle, i u situaciji kada advokat u ime okrivljenog izjavi žalbu a pri tom ne priloži valjanu punomoć, sudija prvostepenog suda istu treba da odbaci kao izjavljenu od strane neovlašćenog lica.

Kada sudija prvostepenog suda za prekršaje utvrdi da je žalba blagovremena, dozvoljena i izjavljena od strane ovlašćenog lica, žalbu sa spisi- 
ma predmeta će dostaviti Višem prekršajnom sudu u roku od 3 dana. Iako rok od 3 dana nije prekluzivni rok, uočava se da se ovaj rok apsolutno ne poštuje, pa čak do granica da se žalba Višem prekršajnom sudu odnosno sadašnjem Veću za prekršaje podnosi i u roku od nekoliko meseci. Ukoliko prvostepeni sud propusti da ceni blagovremenost, dozvoljenost i izjavljenost od strane ovlašćenog lica žalbe, drugostepeni sud je dužan da, ukoliko uoči jedan od navedenih nedostataka, žalbu odbaci.

Inače, rešavajući po žalbi, Viši prekršajni sud kao i sada, žalbu može odbiti kao neosnovanu i potvrditi prvostepenu odluku ili žalbu usvojiti a prvostepenu odluku preinačiti ili ukinuti. No, ovo je predmet nekog drugog razmatranja.

\section{BITNE POVREDE ODREDABA PREKRŠAJNOG POSTUPKA}

Bitne povrede odredaba prekršajnog postupka su povrede prekršajnog postupka (formalnog zakona odnosno procedure). Dakle, u pitanju su povrede koje su učinjene nakon dobijanja zahteva za pokretanje prekršajnog postupka a pre samog pokretanja postupka (povreda iz člana 234. st. 1. tač. 6. Zakona), zatim povrede u toku prvostepenog prekršajnog postupka i na kraju povrede prilikom donošenja odluke.

Povrede odredaba prekršajnog postupka mogu biti osnov za ukidanje odluke samo ukoliko su bitne. Povreda je bitna ukoliko je štetno delovala na donetu odluku. Stoga se bitne povrede odredaba prekršajnog postupka dele na apsolutne povrede i relativne povrede. Kod apsolutno bitnih povreda odredaba prekršajnog postupka koje su u Zakonu o prekršajima u članu 234. st. 1. pojedinačno pobrojane, ne treba dokazivati uzročnu vezu između učinjene povrede i njenog štetnog dejstva na presudu. U Zakonu o prekršajima se u suštini neoborivo pretpostavlja da su te bitne povrede odredaba prekršajnog postupka morale štetno delovati na zakonito i pravilno donošenje odluke u prekršajnom postupku. Do potpunog ili delimičnog ukidanja odluke i vraćanja predmeta na ponovno odlučivanje u prvostepenom prekršajnom postupku mora doći, ako se postojanje ovakve povrede utvrdi. No i pored toga, postoje određene situacije kada Viši prekršajni sud može umesto ukidanja i da preinači presudu. Kada su u pitanju apsolutno bitne povrede odredaba prekršajnog postupka, neke od ovih povreda Viši prekršajni sud povodom žalbe uzima u obzir po službenoj dužnosti, a to su u pitanju bitne povrede iz člana 234. st. 1. tač. 1, 3. i od 7-15. Zakona o prekršajima.

Relativne povrede odredaba prekršajnog postupka su u Zakonu pobrojane u stavu 2. citiranog člana u jednoj opštoj formuli bez nabrajanja i uzimanjem da te povrede postoje ako sudija, odnosno službeno lice u toku prekršajnog postupka ili prilikom donošenja odluke nije primenio ili je pogrešno primenio koju odredbu ovog Zakona ili u toku prekršajnog postupka povredio pravo odbrane, a to je uticalo ili moglo uticati na zakonito i pravilno donošenje odluke u prekršajnom postupku. Da li je povreda 
u konkretnom slučaju imala ili mogla imati taj uticaj, drugostepeni prekršajni sud ceni u svakom konkretnom slučaju koji rešava po žalbi a žalilac se na ove povrede mora pozvati da bi ih sud uopšte uzeo u obzir.

Ovom prilikom bez namere prepisivanja i citiranja Zakona o prekršajima ćemo se zadržati na bitnim povredama odredaba prekršajnog postupka koje su se do sada najčešće pojavljivale u praksi kao i na sada novu bitnu povredu sadržanu u tački 13. stava 1. člana 234. novog Zakona o prekršajima.

\section{Član 234. st. 1. tač. 1. i 2. Zakona}

U dosadašnjoj praksi Veća za prekršaje bitne povrede odredaba prekršajnog postupka koje su u sada važećem Zakonu kao i u novom Zakonu opisane u tačkama 1. i 2. stava 1. člana 234. Zakona se skoro ni ne pojavljuju, što znači da sudije za prekršaje ovakve povrede po pravilu uopšte i ne čine. Dakle, reč je o situaciji kada prekršajni postupak vodi ili je odluku doneo sudija odnosno službeno lice koje je pravosnažnom odlukom izuzeto od vođenja prekršajnog postupka i odlučivanja i ako je prekršajni postupak vodio i odluku doneo sudija odnosno službeno lice organa uprave koji se morao izuzeti. Po pravilu, u praksi organa za prekršaje, sudija po službenoj dužnosti, ukoliko smatra da postoji neki od razloga za izuzeće o tome obavesti starešinu organa, koji odlučuje o izuzeću sudije i predmet dodeljuje drugom sudiji u rad ukoliko usvoji zahtev za izuzeće, a ukoliko je u pitanju izuzeće starešine organa za prekršaje o izuzeću odlučuje Predsednik Veća za prekršaje. Dakle, ovakve situacije se skoro po pravilu razrešavaju u toku prekršajnog postupka, zbog čega se ovakve bitne povrede, ponavljam, skoro uopšte i ne čine.

\section{Član 234. st. 1. tač. 3. Zakona}

Ova bitna povreda se u praksi veoma često pojavljuje. Naime, u Zakonu o prekršajima u poglavlju „Osnovna načela prekršajnog postupka” opisano je načelo utvrđivanja istine, odnosno obaveza suda da istinito i potpuno utvrdi činjenice koje su važne za donošenje zakonite odluke i da sa jednakom pažnjom ispita i utvrdi kako činjenice koje terete okrivljenog tako i one koje mu idu u korist. Dakle, okrivljeni se po pravilu mora ispitati pre donošenja rešenja na način propisan članom 175. Zakona o prekršajima. Izuzeća od ovog pravila su sadržana u članu 85. st. 3. i članu 162. st. 8. Zakona, koji propisuju da ukoliko prvostepeni sudija oceni da ispitivanje okrivljenog nije nužno za utvrđivanje činjenica koje su od važnosti za donošenje zakonite odluke, rešenje o prekršaju se može doneti i bez ispitivanja okrivljenog. Da bi se ovakvo rešenje donelo, potrebno je da sudija u pozivu upozori okrivljenog da će u slučaju njegovog neodazivanja niti dostavljanja pismene odbrane, biti doneto rešenje bez njegovog ispitivanja. Dakle, ova bitna povreda postoji u sledećim situacijama: 1) kada okrivljeni nije pozvan na način propisan članom 162. novog Zakona o prekršajima i 2) kada je okrivljeni uredno pozvan, a prvostepeni sudija je pogrešno ocenio da njegovo ispitivanje nije nužno za utvrđivanje činjeni- 
ca koje su od važnosti za donošenje zakonite odluke. O ovoj povredi Viši prekršajni sud vodi računa po službenoj dužnosti.

\section{Član 234. st. 1. tač. 4. Zakona}

Navedena bitna povreda postoji ako okrivljeni nije poučen o pravu na upotrebu jezika, ili je njemu ili njegovom braniocu protivno njegovom zahtevu uskraćeno pravo da na usmenom pretresu ili u toku ostalih radnji u prekršajnom postupku upotrebljava svoj jezik i da na svom jeziku prati tok usmenog pretresa odnosno postupka. Dakle, ovu bitnu povredu čini sudija koji postupi protivno članu 86. Zakona o prekršajima. Ova odredba se unekoliko razlikuje od odredbe člana 80 . sada važećeg Zakona o prekršajima jer se u potpunosti vrši usklađivanje sa odredbama Zakona o službenoj upotrebi jezika i pisama. Ovo znači da okrivljeni, svedoci i druga lica koja učestvuju u prekršajnom postupku imaju pravo da pri izvođenju pojedinih radnji u postupku ili na usmenom pretresu upotrebljavaju svoj jezik. To dalje, a imajući u vidu odredbe Zakona o službenoj upotrebi jezika i pisama, znači da se postupak može voditi na jeziku nacionalne manjine ukoliko je ista u službenoj upotrebi sedišta suda za prekršaje. Dakle, ova bitna povreda postoji u dva slučaja. Prvi je slučaj kada okrivljeni, svedok ili drugo lice koje učestvuje u prekršajnom postupku nije poučeno o pravu da upotrebljava svoj jezik. Druga je situacija, ukoliko je isti poučen ali mu je u toku postupka na bilo koji način pravo da upotrebljava svoj jezik ili da prati tok postupka na svom jeziku uskraćeno. Da bi ovu situaciju razjasnili, najvažnije je istaći da se učesnik u postupku pita o svom maternjem jeziku, pa ukoliko se izjasni da mu je maternji jezik neki drugi jezik sem srpskog, isti mora da bude poučen da ima pravo da se postupak vodi na njegovom jeziku, da li neposredno na taj način što će sudija za prekršaje postupak voditi na njegovom jeziku ili obezbediti tumača za njegov maternji jezik. Ukoliko se okrivljeni opredeli da se na bilo koji od ovih načina upotrebljava njegov jezik, sudija je dužan da ovo pravo okrivljenom omogući. Pouka i odgovor lica se moraju uneti u zapisnik. Ukoliko se ova povreda odnosi na druge učesnike postupka (npr. oštećenog kao podnosioca zahteva) može se raditi o relativno bitnoj povredi odredaba prekršajnog postupka iz člana 234. st. 2. Zakona.

\section{Član 234. st. 1. tač. 5. Zakona}

Povreda postoji ako je protivno zakonu bila isključena javnost na usmenom pretresu, a u suštini se ogleda u postupanju suprotno odredbama člana 92. st. 1. Zakona, kojim se propisuje da se javnost rada suda obezbeđuje pre svega javnim održavanjem pretresa, objavljivanjem odlu$\mathrm{ka}$, davanjem obaveštenja zainteresovanim licima o toku prekršajnog postupka, upoznavanje javnosti o svom radu putem sredstava javnog informisanja. Istina, u praksi se veoma retko pojavljuje ova bitna povreda, tako da se na njoj više nećemo zadržavati. 


\section{Član 234. st. 1. tač. 6. Zakona}

Mnogo je zanimljivija i mnogo češća u praksi, a postoji ako je sudija, odnosno službeno lice u organu uprave odbacio zahtev za pokretanje prekršajnog postupka protivno odredbama člana 159. ovog Zakona. Odredba člana 159. Zakona o prekršajima propisuje slučajeve u kojima sud, ukoliko utvrdi da ne postoje uslovi za pokretanje prekršajnog postupka, zahtev za pokretanje prekršajnog postupka odbaci rešenjem. To su situacije taksativno pobrojane u 6 tačaka stava 2. ovog člana, no, u praksi su najčešći slučajevi kada sudija odbaci zahtev za pokretanje prekršajnog postupka smatrajući da je nastupila zastarelost za pokretanje prekršajnog postupka, odnosno da je od dana učinjenog prekršaja prošlo više od godinu dana do momenta razmatranja podnetog zahteva. Greške se najčešće dešavaju u situacijama kada sudija pogrešno smatra da je prekršaj učinjen određenog datuma, a u suštini se radi o tzv. trajnom prekršaju gde je okrivljeni u prekršaju svaki put kada se taj prekršaj otkrije. To bi na primer bilo kod prekršaja neisticanja firme, kao i kod drugih prekršaja nečinjenja kod kojih obaveza na činjenje nije vezana za rok. U praksi novosadskog Veća za prekršaje više puta se desilo da je sudija odbacio zahtev za pokretanje prekršajnog postupka smatrajući da je zahtev podneo neovlašćeni organ, odnosno neovlašćeno lice, a u tim situacijama zahtev za pokretanje prekršajnog postupka je podneo javni tužilac. Kako je javni tužilac univerzalni podnosilac zahteva za pokretanje prekršajnog postupka i on je uvek ovlašćen da podnosi zahtev, bez obzira na to što u konkretnom slučaju ne vrši nadzor nad primenom tog propisa, dakle javni tužilac, pored ovlašćenog organa iz tog posebnog Zakona se uvek može pojaviti kao podnosilac zahteva za pokretanje prekršajnog postupka. Pored ovih situacija, česta je situacija da se zahtev odbaci jer sudija proceni da radnja opisana u zahtevu nije prekršaj, jer sadrži i obeležja nekog drugog protivpravnog ponašanja, krivičnog dela ili privrednog prestupa, ali pri tom sudija nema u vidu zaštitni objekat tog prekršaja, pa će Viši prekršajni sud biti prinuđen da ovakvo rešenje o odbacivanju zahteva ukine zbog navedene bitne povrede odredaba prekršajnog postupka.

\section{Član 234. st. 1. tač. 7. Zakona}

Ova bitna povreda se unekoliko razlikuje od istovetne bitne povrede iz prethodnog Zakona o prekršajima, jer nov Zakon o prekršajima propisuje više vrsta odluka koje donosi Sud za prekršaje. Ova bitna povreda postoji ukoliko je sudija obustavio prekršajni postupak protivno odredbama člana 216. Zakona ili je doneo presudu kojom se okrivljeni oslobađa krivice protivno odredbama člana 218. Zakona.

Podsećanja radi, član 216. propisuje situacije kada sud donosi rešenje kojim se obustavlja prekršajni postupak. Razlozi za obustavu prekršajnog postupka su formalne prirode a to su kada je postupak vođen bez zahteva, kada sud nije stvarno nadležan za vođenje prekršajnog postupka, zatim slučaj tzv. ,presuđene stvari”, situacija kada je okrivljeni u krivičnom postupku odnosno postupku po privrednom prestupu pravosnažno 
oglašen krivim za isto delo, postojanje diplomatskog imuniteta, zastarelosti, smrti fizičkog odnosno prestanka postojanja okrivljenog pravnog lica i odustanka od zahteva od strane ovlašćenog podnosioca zahteva. Prekršajni postupak se može obustaviti protiv učinioca prekršaja za koji je propisana novčana kazna ukoliko je on dobrovoljno posle izvršenja prekršaja a pre pokretanja prekršajnog postupka otklonio protivpravno stanje ili nadoknadio štetu koju je izazvao prekršajem. Jedino u ovoj poslednjoj situaciji donosi se rešenje o obustavi postupka iako sud pre donošenja ovakvog rešenja mora da utvrdi pojedine činjenice i okolnosti odnosno da izvodi dokaze.

$\mathrm{Na}$ osnovu člana 218. Zakona, presuda kojom se okrivljeni oslobađa krivice se donosi u slučajevima ukoliko sud utvrdi da delo za koje se okrivljeni tereti nije propisano kao prekršaj. Članom 2. Zakona je data definicija prekršaja kao protivpravne skrivljeno izvršene radnje koja je propisom nadležnog organa određena kao prekršaj. Iz navedenog proizilaze bitna obeležja prekršaja a to su: 1) protivpravnost; 2) krivica; 3) radnja ili propuštanje učinioca prekršaja i 4) propisanost u zakonu ili drugom propisu. Dakle, ukoliko radnje ili propuštanje nekog lica ne sadrže neki od navedenih elemenata ne mogu se smatrati prekršajem. Pri tom treba imati u vidu da se radi o radnji ili propuštanju koje je navedeno u činjeničnom opisu prekršaja u zahtevu za pokretanje prekršajnog postupka bez obzira na pravnu kvalifikaciju podnosioca zahteva. U dosadašnjoj praksi Veća za prekršaje ova bitna povreda najčešće postoji kada je radnja u vreme činjenja ili propuštanja bila propisana kao prekršaj, pa je nakon toga došlo do promene propisa kojim je prekršaj uređen, tako da u novom propisu takva radnja više nije sankcionisana kao prekršaj. Najčešći primeri u poslednje vreme su pojedini prekršaji iz Zakona o radu. Druga je situacija kada je Zakonom propisana obaveza ponašanja, a za to ponašanje nisu propisane prekršajne sankcije. Najočitiji primer je prekršaj upravljanja neregistrovanom traktorskom prikolicom iz Zakona o bezbednosti saobraćaja na putevima, gde je u dispozitivnoj odredbi propisana obaveza da traktorska prikolica bude registrovana, a postupanje protivno ovoj odredbi, najverovatnije omaškom zakonodavca, nije sankcionisano kao prekršaj. Presudu kojom se okrivljeni oslobađa krivice, sud će izreći ukoliko ima okolnosti koje isključuju prekršajnu odgovornost okrivljenog. Prekršajna odgovornost je psihičko stanje učinioca prekršaja i njegov psihički odnos prema prekršajnom delu na osnovu kojih mu se učinjeni prekršaj može staviti na teret. Članom 17. Zakona, propisani su subjekti i uslovi prekršajne odgovornosti, te je u stavu 2. navedeno da je fizičko lice odgovorno za prekršaj ako je u vreme izvršenja prekršaja bilo uračunljivo i prekršaj izvršilo sa umišljajem ili iz nehata, da pod istim uslovima odgovara i odgovorno lice u pravnom licu kao i odgovorno lice u državnom organu i preduzetnik. Pravno lice je odgovorno za prekršaj učinjen skrivljeno preduzetom radnjom ili propuštanjem dužnog nadzora od strane organa upravljanja ili odgovornog lica ili skrivljenom radnjom drugog lica koje je u vreme izvršenja prekršaja bilo ovlašćeno da postupa u ime prav- 
nog lica. U članovima 18, 19. i 20. Zakona su propisani elementi prekršajne odgovornosti a to su uračunljivost, krivica i stvarna zabluda i ukoliko se kod fizičkih lica utvrdi da jedan od ovih elemenata ne postoji sudija sa pravom može da donese oslobađajuću presudu iz razloga propisanih članom 218. st. 1. tač. 2. Zakona. U protivnom, kada su fizička lica u pitanju čini bitnu povredu odredaba prekršajnog postupka. U ovom Zakonu je prvi put naglašeno da svi ovi uslovi moraju da postoje i kada je u pitanju odgovornost odgovornog lica u pravnom licu iz koje, ukoliko se ona utvrdi, proizilazi i odgovornost samog pravnog lica pod uslovom da je odgovorno lice prekršaj učinilo postupajući u ime i za račun okrivljenog pravnog lica.

\section{Član 234. st. 1. tač. 8. Zakona}

Ovu bitnu povredu čini sud koji je doneo presudu iako zbog stvarne nenadležnosti nije mogao da sudi u toj stvari. Najočigledniji primer postojanja ove bitne povrede je situacija ukoliko sudovi za prekršaje postupaju i vode postupak povodom prekršaja za koje je propisana kazna u fiksnom iznosu, a za koje su stvarno nadležni organi uprave.

\section{Član 234. st. 1. tač. 9. Zakona}

Član 220. Zakona propisuje situacije kada se presuda objavljuje, te propisuje obavezu prvostepenog suda da u zapisnik unese izreku presude sa konstatacijom da je presuda usmeno saopštena, da je dato kratko obrazloženje presude i uputstvo o pravnom leku. Ovu bitnu povredu čini sudija koji usmeno saopštenu odluku nije uneo u zapisnik.

\section{Član 234. st. 1. tač. 10. Zakona}

Sledeća bitna povreda odredaba prekršajnog postupka koja je propisana i u sada važećem Zakonu o prekršajima nije retka, a ista najčešće proizilazi iz nedovoljno jasno podnetih zahteva za pokretanje prekršajnog postupka, te nekritičkim preuzimanjem pravnih kvalifikacija iz zahteva za pokretanje prekršajnog postupka od strane postupajućeg sudije. Naime, nije retka situacija da podnosilac zahteva činjeničnim opisom iz zahteva za pokretanje prekršajnog postupka okrivljenog tereti za dva ili više prekršaja, a isto pravno kvalifikuje kao jedan prekršaj. To je npr. slučaj kada tržišni inspektor u podnetom zahtevu za pokretanje prekršajnog postupka utvrdi više protivpravnosti koje su propisane u više stavova člana 16. Zakona o uslovima za obavljanje prometa robe, vršenje usluga u prometu robe i inspekcijskom nadzoru koji su svi pravno kvalifikovani kao prekršaj iz člana 53. st. 1. tač. 10. Zakona, te sudija umesto da okrivljenog oglasi odgovornim za više prekršaja iz citiranog člana Zakona okrivljenog oglasi odgovornim samo za jedan od tih prekršaja. Takođe je česta situacija u istom Zakonu kada tržišni inspektor zbog prekršaja uz potvrdu privremeno oduzme robu, a sudija ne odluči o privremeno oduzetoj robi, dakle rešenjem ne izrekne zaštitnu meru oduzimanja predmeta niti naloži vraćanje robe. Najčešće ovakva greška postoji kada sudija obustavi prekr- 
šajni postupak jer je nastupila zastarelost gonjenja za taj prekršaj a o robi uopšte ne odluči.

\section{Član 234. st. 1. tač. 11. Zakona}

Navedena bitna povreda postoji ako je sud odnosno organ uprave odlučio mimo zahteva za pokretanje prekršajnog postupka. Ova povreda je unekoliko slična prethodnoj, jer se u suštini tiče objektivnog identiteta između podnetog zahteva za pokretanje prekršajnog postupka i izreke prvostepene odluke. Kako se na osnovu člana 215. Zakona, odluka odnosi samo na lice koje se zahtevom za pokretanje prekršajnog postupka tereti (subjektivni identitet) i samo na prekršaj koji je predmet podnetog zahteva (objektivni identitet), dužnost suda za prekršaje je da utvrdi da li je lice koje je sa generalijama navedeno u podnetom zahtevu izvršilo radnju koja je opisana u podnetom zahtevu za pokretanje prekršajnog postupka. Ovo znači da ukoliko sud i utvrdi da okrivljeni tu i takvu radnju nije izvršio ali jeste izvršio neku drugu radnju koja takođe čini obeležje prekršaja, ne može menjati činjenični opis iz zahteva za pokretanje prekršajnog postupka i okrivljenog oglasiti odgovornim za neki drugi prekršaj. Ukoliko ovako postupi, sud čini navedenu bitnu povredu odredaba prekršajnog postupka.

\section{Član 234. st. 1. tač. 12. Zakona}

Sledeću bitnu povredu sud čini ukoliko se odluka zasniva na dokazu na kome se po odredbama ovog Zakona ne može zasnovati, ako je, s obzirom na druge dokaze, očigledno da bi i bez tog dokaza bila doneta ista odluka. Tu se najčešće radi o postupanju protivno članu 185. Zakona koji propisuje oslobađanje od dužnosti svedočenja i člana 186. koji navodi koje su posledice povrede prava svedočenja. Dakle, ukoliko bračni drug, srodnici pobrojani u zakonu, usvojenik i verski ispovednik nisu upozoreni da mogu biti oslobođeni od prava na svedočenje, ili ukoliko se od njih ipak traži svedočenje bez obzira na takvo upozorenje, na ovakvom dokazu se odluka ne može zasnivati. No, ukoliko drugi izvedeni dokazi bez ovog dokaza upućuju na isto utvrđeno činjenično stanje i ukoliko je očigledno da bi i bez tog dokaza bila doneta ista odluka, ova bitna povreda ne postoji, dakle veće Višeg prekršajnog suda u svakom konkretnom slučaju utvrđuje da li je s obzirom na navedeno, ova bitna povreda učinjena.

\section{Član 234. st. 1. tač. 13. Zakona}

Ova, apsolutna bitna povreda odredaba prekršajnog postupka je novina u ovom Zakonu o prekršajima i ona postoji ukoliko se odluka zasniva na iskazu okrivljenog koji nije bio upozoren na pravo da uzme branioca po svom izboru ili da bude ispitan u prisustvu branioca. Elementarna ljudska prava propisana Evropskom konvencijom o ljudskim pravima kao i Ustavom Republike Srbije su na ovaj način u većoj meri zaštićena i ona za prvostepenog sudiju znače obavezu da prilikom prvog ispitivanja okrivljenog upozore na pravo da uzme branioca u tom prekršajnom postupku. 
Sudija je dužan da ovo pitanje i odgovor okrivljenog unese u zapisnik. Ukoliko se okrivljeni opredelio da angažuje branioca u tom prekršajnom postupku, sudija je dužan da zastane sa postupkom, da pozove okrivljenog i njegovog branioca na sledeće ročište radi omogućavanja odbrane u prisustvu branioca. U protivnom, sudija čini navedenu bitnu povredu odredaba prekršajnog postupka, o kojoj Viši prekršajni sud vodi računa po službenoj dužnosti.

\section{Član 234. st. 1. tač. 14. Zakona}

Bitna povreda odredaba prekršajnog postupka o kojoj Viši prekršajni sud takođe vodi računa po službenoj dužnosti je povreda načela zabrane preinačenja na gore. Ova povreda se može izvršiti od strane prvostepenog suda u situaciji ukoliko je osuđujuća presuda od strane Višeg prekršajnog suda ukinuta po žalbi okrivljenog a prvostepeni sud donese novu presudu koja je nepovoljnija po okrivljenog. Zabrana se ogleda u zabrani osude na strožu pravnu kvalifikaciju i strožu prekršajnu sankciju i osim toga ne obuhvata nikakva druga ograničenja koja bi inače bila moguća.

\section{Član 234. st. 1. tač. 15. Zakona}

I poslednja, apsolutno bitna povreda odredaba prekršajnog postupka o kojoj Viši prekršajni sud vodi računa po službenoj dužnosti se tiče povreda postupka u fazi izrade odluka.

Izreka odluke je nerazumljiva ako ista u svom činjeničnom opisu ne sadrži jasno i razumljivo činjenični opis prekršaja upodobljen odredbi iz propisa kojim je prekršaj određen, ukoliko izreka ne sadrži osnovne elemente prekršaja kao što je protivpravnost, ako se iz izreke odluke ne može videti na koji način će se izvršiti novčana kazna ili kazna zatvora ili zaštitna mera. Izreka je protivrečna sama sebi ili razlozima presude ukoliko iz jednog dela izreke proizilazi da se novčana kazna ima izvršiti pre pravosnažnosti odluke, a zatim se navodi da je rok plaćanja kazne 15 dana od dana pravosnažnosti iste. Primeri nerazumljive izreke presude i izreke koja je protivrečna sama sebi ili razlozima su sledeći: označenje da je okrivljeni upravljao vozilom pod uticajem alkohola, bez naznačenja količine alkohola u organizmu, konstatacija da okrivljeni upravljajući vozilom nije ustupio prvenstvo prolaza oštećenom te izazvao saobraćajnu nezgodu bez naznačenja zbog čega je drugi učesnik u saobraćaju imao prvenstvo prolaza (pravilo desne strane, saobraćajni znak, skretanje levo dok vozilo iz suprotnog smera zadržava pravac svog kretanja i sl.). Izreka je takođe nerazumljiva ukoliko se radi o sticaju više prekršaja i pri tom se izriče zaštitna mera bez navođenja za koji prekršaj se ova zaštitna mera izriče.

Presuda, odnosno odluka nema razloga o odlučnim činjenicama u situaciji kada se u obrazloženju navodi da je neka činjenica dokazana na osnovu iskaza svedoka a ne navedu se ni imena tih svedoka niti sadržaj njihovih iskaza, zatim ukoliko sudija nije dao razloge zašto ne poklanja veru iskazima nekih svedoka a zadovoljio se konstatacijom da su iskazi 
svedoka nejasni i nepouzdani. Ovo naročito stoga što savesna i brižljiva ocena svakog dokaza posebno i svih dokaza zajedno jeste rukovodni princip za prvostepeni sud za prekršaje kada po izvedenim dokazima ceni dokaznu snagu onoga do čega je došao tokom postupka, dakle to je ustvari njegovo zaključivanje zašto i na koji način izvedeni dokazi diktiraju donošenje odluke, a što podrazumeva dovoljno i neprotivrečno obrazložen stav u skladu sa pravilima logike, a ne samo jednostavno zaključivanje (npr. o prihvatanju pojedinog dokaza kao uverljivog i sl.). Izvođenje takvih jednostavnih i nemotivisanih zaključaka čini navedenu bitnu povredu odredaba prekršajnog postupka.

Valjani razlozi takođe moraju da stoje i kod obrazlaganja odluke o prekršajnim sankcijama. Tako u situaciji kada je za određeni prekršaj zakonom alternativno propisana novčana kazna i kazna zatvora, presuda nema razloga o odlučnim činjenicama ukoliko se sudija u izreci rešenja opredelio da okrivljenom izrekne kaznu zatvora kao težu po vrsti, a da pri tom nije dao razloge zbog čega se za tu kaznu opredelio (okolnosti koje ukazuju na veći stepen odgovornosti okrivljenog ili nastupele teže posledice). Presuda nema razloga o odlučnim činjenicama i u situaciji kada odluka o izrečenoj kazni uopšte nije obrazložena, te ukoliko ne sadrži potpune podatke o osobito olakšavajućim okolnostima na osnovu kojih je izvršeno ublažavanje kazne, itd.

Znatna protivrečnost između onoga što se navodi u razlozima presude o sadržini isprava ili zapisnika o iskazima datim u postupku i samih tih isprava ili zapisnika, postoji u situaciji ukoliko okrivljeni prilikom saslušanja pred prvostepenim sudom za prekršaje osporava izvršenje prekršaja, a sud u obrazloženju rešenja navodi da je presudu kojom okrivljenog oglašava krivim doneo na osnovu njegovog priznanja. Ova protivrečnost može da postoji i između različitih zapisnika kao što je zapisnik o uviđaju saobraćajne nezgode, zapisnik o izvršenoj inspekcijskoj kontroli od strane podnosioca zahteva itd., sa razlozima presude.

Naravno, u ovom momentu je neophodno naglasiti da ukoliko je sud okrivljenom i podnosiocu zahteva uručio, odnosno dostavio samo prepis izreke presude (član 220. Zakona), isti može da učini samo deo ove bitne povrede i to deo koji se odnosi na izreku, jer ovakva presuda ne sadrži obrazloženje.

Do sada je bilo reči o apsolutno bitnim povredama odredaba prekršajnog postupka, dakle o povredama kod kojih postoji neoboriva pretpostavka da su iste bile ili mogle biti od uticaja na donošenje zakonite odluke.

\section{Relativne povrede}

Pored toga, bitna povreda odredaba prekršajnog postupka postoji i ukoliko sudija odnosno službeno lice u svim fazama, dakle u toku prekršajnog postupka ili prilikom donošenja odluke nije primenio ili je pogrešno primenio koju odredbu ovog Zakona, ili je u toku prekršajnog postupka povredio pravo odbrane, a to je uticalo ili moglo uticati na zakoni- 
to i pravilno donošenje odluke. Da bi odluka mogla da se ukine zbog ove relativno bitne povrede odredaba prekršajnog postupka potrebno je sledeće: 1) da žalilac u žalbi ukaže na to koja je od odredaba Zakona o prekršajima povređena; 2) da ukaže da je postojanje ove povrede uticalo na zakonito i pravilno donošenje te odluke. Ova dva uslova moraju da budu kumulativno ispunjena da bi prvostepena odluka bila ukinuta (ili u pojedinim slučajevima preinačena) zbog navedene relativno bitne povrede odredaba prekršajnog postupka.

\section{PONAVLJANJE PREKRŠAJNOG POSTUPKA}

Pravosnažno okončan prekršajni postupak se može ponoviti pod uslovima propisanim članom 249. Zakona o prekršajima a uslovi su sledeći:

1) ako se dokaže da je odluka zasnovana na lažnoj ispravi ili lažnoj izjavi svedoka ili veštaka. Ponavljanje prekršajnog postupka koji se zasniva na ovom osnovu zahteva postojanje dveju pravosnažnih odluka i to jedne koja konstatuje postojanje lažnog iskaza svedoka ili veštaka i druge, koja je zasnovana na tom i takvom lažnom iskazu. Dakle, prvostepeni sudija za prekršaje u ovoj situaciji mora da utvrdi postojanje zasnovanosti presude na takvim nepodobnim dokazima a zatim i postojanje okolnosti da je taj iskaz svedoka ili veštaka lažan. Da bi se moglo govoriti o ponavljanju prekršajnog postupka potrebno je da su oba uslova kumulativno stečena;

2) ako se dokaže da je odluka doneta usled krivičnog dela sudije ili drugog službenog lica koje je učestvovalo u postupku. Za ponavljanje po ovom osnovu traži se da je do odluke došlo usled krivičnog dela sudije ili drugog službenog lica, što znači da se u suštini presuda mora zasnovati na krivičnom delu sudije ili tog službenog lica. I ovde je potrebno da postoje kumulativno dva uslova da bi se dozvolilo ponavljanje postupka a to je prvi, da je krivično delo izvršeno a drugi, da presuda nije pravilna. Teoretski je moguća situacija da je sudija izvršio krivično delo primanja mita ili zloupotrebe službenog položaja, što znači da je uzeo novac ili neku vrednost a u suštini doneo presudu koja je zasnovana na zakonu. Zbog toga prilikom odlučivanja o postojanju razloga za ponavljanje postupka sudija mora da ima u vidu obe činjenice, dakle i krivično delo i pravilnost prethodne osuđujuće presude;

3) ako se utvrdi da je lice koje je kažnjeno za prekršaj za istu radnju već jednom kažnjeno u prekršajnom postupku. Cilj dozvole ponavljanja postupka po ovom osnovu je da se isključi suđenje istom licu za isti prekršaj dva puta. Ukoliko podnosilac zahteva za ponavljanje postupka dokaže da je za istu radnju već jednom kažnjen u prekršajnom postupku, sud će dozvoliti ponavljanje postupka radi obustave onog prekršajnog postupka u kome se ponavljanje traži;

4) ako se iznesu nove činjenice ili podnesu novi dokazi koji bi sami za sebe ili u vezi sa ranijim dokazima doveli do drugačije odluke da su 
bili poznati u ranijem postupku. Ponavljanje postupka po ovom osnovu može se dozvoliti samo ako su oni u stanju da presudu kojom je okrivljeni oglašen krivim pretvore u oslobađajuću presudu ili su u pitanju dokazi koji ukazuju na takve olakšavajuće okolnosti na strani okrivljenog da je moguće pretpostaviti da bi se nakon izvođenja tih dokaza okrivljenom izrekla opomena ili primenio institut ublažavanja kazne. Ovo podrazumeva da se ponavljanje traži i dozvoljava samo u situaciji kada je doneta presuda kojom se okrivljeni oglašava krivim, dakle ponavljanju postupka nema mesta imajući u vidu da je on i ustanovljen isključivo u korist okrivljenog u situaciji kada je prekršajni postupak rešenjem obustavljen ili je doneta oslobađajuća presuda. Pri tom treba istaći da se ponavljanje postupka po ovom osnovu ne treba dozvoliti ukoliko su nove činjenice i novi dokazi takvi koji bi izazvali samo blaže odmeravanje kazne u zakonom propisanom rasponu za taj prekršaj. Karakteristični slučajevi iz prakse kada je prvostepeni sudija osnovano dozvolio ponavljanje postupka je bilo kada je uz zahtev za ponavljanje postupka pružen validan dokaz da je okrivljeni u vreme izvršenja prekršaja bio neuračunljiv. Nasuprot iznetom, u situaciji kada ponavljanje postupka traži podnosilac zahteva, isto se može tražiti kada je prekršajni postupak rešenjem obustavljen, kod osuđujuće i oslobađajuće presude, a u slučaju dozvole ponavljanja nova presuda može da bude po okrivljenog nepovoljnija od prethodne. U tome se ponavljanje postupka u prekršajnom postupku u suštini razlikuje od pravog ponavljanja krivičnog postupka.

Zahtev za ponavljanje postupka mogu podneti kažnjeni i njegov branilac i podnosilac zahteva, a posle smrti kažnjenog lica koja mogu da izjave žalbu u korist okrivljenog. Rok za podnošenje zahteva je objektivan i on uvek iznosi godinu dana od dana pravosnažnosti odluke. O zahtevu za ponavljanje postupka odlučuje Sud odnosno organ uprave koji je doneo prvostepenu odluku a podnosilac zahteva je dužan da navede po kom se zakonskom osnovu traži ponavljanje postupka i kojim se dokazima potkrepljuju činjenice na kojima se zahtev zasniva. Ako zahtev ne sadrži te podatke odbaciće se presudom odnosno rešenjem. Ovakvo zakonsko rešenje propisuje da je teret dokazivanja za postojanje razloga i okolnosti propisanih članom 249. st. 1. tač. $1-4$. Zakona na licu koje podnosi zahtev za ponavljanje prekršajnog postupka. Ukoliko uz zahtev ne postoje odgovarajući dokazi isti se odbacuje. Sud će zahtev odbaciti kada na osnovu zahteva i dokaza iz spisa predmeta iz ranijeg postupka utvrdi da je zahtev podnelo neovlašćeno lice, usled neblagovremenosti ili ukoliko nema zakonskih uslova za ponavljanje postupka ili činjenice i dokazi na kojima se zahtev zasniva očigledno nisu podobni da se na osnovu njih dozvoli ponavljanje. Ovo znači da će prvostepeni sud zahtev odbaciti u situaciji ukoliko je za te činjenice i okolnosti ranije znao i iste cenio i doneo odgovarajuću odluku ili ukoliko za te činjenice i okolnosti nije imao saznanja a procenjuje da i u situaciji da su bile poznate u vreme odlučivanja ne bi dovele do drugačije odluke. Zahtev za ponavljanje postupka se može podneti i nakon što je odluka izvršena. Ukoliko sud ne odbaci zahtev za 
ponavljanje postupka, ponoviće postupak u obimu koji je neophodan da se utvrde činjenice zbog kojih je podnet i u zavisnosti od toga zahtev će se rešenjem odbiti ili će se novom odlukom prethodna ukinuti u celosti ili delimično. Protiv rešenja kojim se dozvoljava ponavljanje postupka žalba nije dozvoljena.

Kao i svaki drugi vanredni pravni lek i zahtev za ponavljanje postupka ne odlaže u principu izvršenje odluke, ali je ostavljeno diskreciono pravo odnosno ocena prvostepenom sudu da ukoliko oceni da zahtev može biti uvažen, odluči da se izvršenje odloži dok se ne odluči o zahtevu za ponavljanje postupka. Ukoliko se sud opredelio da dozvoli ponavljanje postupka ovo rešenje odlaže izvršenje odluke protiv koje je ponavljanje dozvoljeno. 